Bangladesh J. Bot. 49(2): 305-312, 2020 (June)

\title{
GENETIC VARIABILITY AND CHARACTER ASSOCIATION AMONG THE YIELD AND YIELD ATTRIBUTING COMPONENTS IN LENTIL (LENS CULINARIS MEDIK.)
}

\author{
VINOD KUMAR* \\ Jawaharlal Nehru Krishi Vishwa Vidyalaya, College of Agriculture, \\ Powarkheda, Hoshangabad 461110 (MP)
}

Keywords: Heritability, Principal component analysis, Variability, Lentil

\begin{abstract}
Twenty one advanced lines of lentil including three checks were selected. The observations were recorded on five randomly selected plants of each genotype under each replication and per plant. Data were obtained by averaging the values. (i) Pre-harvest observations - days to flowering, days to maturity, (ii) postharvest observations - plant height $(\mathrm{cm})$, pods per plant, no. of branches per plant, yield per plot (kg/ha), 100seed weight and plant stand (\%) considered .The study revealed that characters viz., 100-seed weight (177.5), plant height (66.1) and seed yield (20.7) showed high GCV apprises. In the present investigation out of eight, only seven components (PCs) exhibited more than 5 Eigen value, and showed about $91.289 \%$ total variability among the studied traits. Among the others characters days to maturity was positively and significantly correlated by days to $50 \%$ flowering and number of pods per plant suggesting early maturity or late maturity depends on flowering which are directly correlated with seed yield and selection of more number of pods plant gives maximum yield.
\end{abstract}

\section{Introduction}

Lentil is important Rabi pulse crop next to chickpea with production of 1.13 million tonnes for $1.43 \mathrm{~m} / \mathrm{ha}$ area in India (Anon. 2018). In north-eastern parts of the country, lentil is also cultivated as paira crop with rice. It is cultivated for its seed and mostly eaten as Dhal. The seed is decorticated and split. The primary product is the seed which has relatively higher contents of protein, carbohydrate and calories compared to other legumes and is the most desired crop because of its high average protein content and fast cooking characteristic in many lentil producing regions. Lentil residues contain about $10.2 \%$ moisture, $1.8 \%$ fat, $4.4 \%$ protein, $50 \%$ carbohydrate, $21.4 \%$ fiber and $12.2 \%$ ash (Muehlbauer et al. 1985). Lentil is a diploid ( $2 \mathrm{n}=14$ chrmosomes) self-pollinated annual cool season legume crop. Many biotic and abiotic stresses influence lentil yield all over the world i.e. diseases, insect and along with drought, heat salt susceptibility and iron deficiency. Plant breeders must have a mean of choosing the accessions most likely to possess the trait of interest. Until recently, most of characterization and evaluation has been based on the recording of either qualitative and or quantitative morphological characters using standard descriptions. Present investigation was undertaken to estimate the variability parameters and correlation coefficients between grain yield and its components characters in lentil genotypes.

\section{Materials and Methods}

The present investigation was carried out in the experimental fields of the Regional Agricultural Research Station, Jawaharlal Nehru Krishi Vishwa Vidyalaya, Sagar, (M.P.) during Rabi season of 2014 with 21 lentil improved lines.

The experiment was carried out under RCBD. Each genotype was accommodated in 6 row plot of $4 \mathrm{~m}$ length with row to row and plant to plant spacing of 30 and $5 \mathrm{~cm}$, respectively. The experiment was conducted under semi irrigated and medium fertility conditions. Twenty one

*Author for correspondence: <vinod.asco.ujn@gmail.com>. 
advanced lines including three checks were used for this experiment. All genotypes collected from project co-coordinator, All India Coordinated Research Project on MULLaRP, IIPR, Kanpur.

Table 1. List of genotypes, source and pedigree.

\begin{tabular}{|c|c|c|c|}
\hline Sl. No. & Genotypes & Source & Pedigree \\
\hline 1. & JL-3 & JNKVV, Jabalpur & Local selection from Sagar M.P. \\
\hline 2. & IPL-81 & IIPR, Kanpur & K75 × PL 639 \\
\hline 3. & DPL-62 & IIPR, Kanpur & JLS $1 \times$ LGI 71 \\
\hline 4. & IPL-316 & IIPR, Kanpur & Sehore $74-3 \times$ DPL 58 \\
\hline 5. & IPL-330 & IIPR, Kanpur & KL $178 \times$ DPL62 \\
\hline 6. & RKL-603-1 & ARS, Kota & L $4682 \times$ DPL 62 \\
\hline 7. & IPL-331 & IIPR, Kanpur & $(94 / 1570 \times$ DPL 98) DPL 62 \\
\hline 8. & VL-523 & Almora & VL $120 \times$ DPL 15 \\
\hline 9. & DKL-37 & Dhaulakaun & DPL-6 × PL-5) \\
\hline 10. & LL-1242 & PAU, Ludhiana & LL $148 \times$ L 4603 \\
\hline 11. & L-4714 & IARI, New Delhi & Precoz $\times$ DPL 15 \\
\hline 12. & IPL-329 & IIPR, Kanpur & KL $178 \times$ DPL 62 \\
\hline 13. & PL-164 & Pantnagar & DPL $15 \times$ L 4188 \\
\hline 14. & KLB -13-6 & CSA Kanpur & KLB $08-4 \times$ KLB 303 \\
\hline 15. & L-4715 & IARI, New Delhi & Sehore $74-3 \times$ Precoz \\
\hline 16. & PL-157 & Pantnagar & PL $02 \times$ DPL 58 \\
\hline 17. & RKL-1003-21C & ARS, Kota & Mutant of DPL 62 \\
\hline 18. & IPL-332 & IIPR, Kanpur & $($ IPL $517 \times$ DPL 62) DPL 62 \\
\hline 19. & LL-1318 & PAU, Ludhiana & DPL $15 \times$ LL 992 \\
\hline 20. & PL- 160 & Pantnagar & PL $02 \times$ DPL 15 \\
\hline 21. & RVL-12-5 & Sehore & JL $3 \times$ DPL 62 \\
\hline
\end{tabular}

The observations were recorded on five randomly selected plants of each genotype under each replication and per plant, data were obtained by averaging the values. (A) Pre-harvest observations - days to flowering, days to maturity, (B) post-harvest observations - plant height $(\mathrm{cm})$, pods/plant, No. of branches/plant, yield kg/ha, 100-seed weight in $\mathrm{g}$ and plant stand (\%).

The mean values of from randomly selected plants while the difference between the lowest and highest values for each character were taken as the range. Estimate of genetic advance (GA) was done by Robinson et al. (1949). To test the significance of correlation coefficients, the estimated values were compared with the tabler values (Fisher and Yates 1957) at $n$ - 2 degrees of freedom at 5 and $1 \%$ level of significance, where $n$ being the sample size on which correlation is based. Path analysis was made as described by Dewey and Lu (1959) and Ramanujam and Rai (1963) to assess direct and indirect influences of various components on grain yield. Statistical analysis done with the help of SPSS statistical software. Based on the theoretical arguments of the PCA described by Hair et al. (2005) the significant factor loading values higher than or equal to 0.7 were used to identify the most important variables and attributes in each dimension, or principal components (PCs). The purpose of principal component analysis is to derive a small number of linear combinations (principal components) of a set of variables that retain as much information in the original variables as possible. PCA is a well-known method of dimension reduction that can be used to reduce a large set of variables to a small set that still contains most of 
the information in the large set (Massay 1965). It is a mathematical procedure that transforms a number of (possibly) correlated variables into a (smaller) number of uncorrelated variables called principal components. The first principal component accounts for as much of the variability in the data as possible and each succeeding component accounts for as much of the remaining variability as possible.

\section{Results and Discussion}

Variability indicates a way to describe variance between characters and a scope for selection to plant. Variability is the base of plant breeding because to improve any character of plant variability is a prerequisite. Analysis of variance suggested that differences among the genotypes were highly significant for all the characters (Table 2). Assessment of variability, heritability and genetic advance in a set of 21 lentil genotypes for all the 8 traits was done to determine the extent of variability present in the material. Genotypic and phenotypic co-efficient of variation also indicated the same. In general, it was observed that the phenotypic co-efficient of variation was higher in magnitude for all the traits, than its corresponding genotypic co-efficient indicating the masking influence of environment in the expression of the traits studied.

The study revealed that characters showed high GCV viz., 100-seed weight (177.5), plant height (66.1) and seed yield (20.7) showed high GCV apprises. This is an indicative of less manageable fluctuations; hence it is given to great emphasis should be given on these characters, while formulating breeding programme with this material. High GCV for the characters 100-seed weight, plant height and seed yield earlier also were reported by Hissan et al. (2018), However, the estimates of heritability in broad sense was high for most of the traits viz., day to maturity $(0.95), 100$-seed weight $(0.85)$, days to flowering $(0.78)$ and seed yield $(0.70)$. The results are quite in agreement with the findings obtained by earlier workers Al-Aysh (2014) for seed yield and Tyagi and Khan (2010) for 100-seed weight and grain yield. The magnitude of PCV ranged 0.62 for No. of pods/plant to 192.6 for 100-seed weight and GCV ranged from 0.47 to 177.5 for the same character.

Difference between the PCV and GCV was high for plant height, no. of branches/plant and 100-seed weight. In the present investigation, high to moderate heritability coupled with high to moderate genetic advance as percentage of mean was exhibited for four traits viz., days to flowering, days to maturity, grain yield and 100-seed weight. The trait plant height $(0.25)$ showed medium heritability with high genetic advance (30.7). Plant stand (7.3) exhibited moderate genetic advance and moderate heritability. The presence of high heritability coupled with high-expected genetic advance indicated predominance of additive gene action in the expression of these characters and consequently greater chance of improving these traits through simple selection. These results are in conformity with the findings of Mekonnen et al. (2014) for 100-seed weight and seed yield.

Higher magnitude of genotypic correlation helps in selecting genetically controlled characters and gives a better chance for seed yield improvement than that would be expected on the basis of phenotypic association alone (Robinson et al.1951). The correlation matrix depicting trait associations is presented in Table 4 . The tables revealed that plant stand, days to maturity and plant height are significantly and positively correlated with seed yield $(0.43)$ at both levels. The degree of association was highest between pant stand and seed yield. It was followed by maturity and plant height. Hissan et al. (2018) also suggested that seed yield is positively and significantly correlated with days to maturity and flowering, which means late flowering due to temperate conditions. Among the others characters days to maturity was found to positively and significantly correlated by days to $50 \%$ flowering $(0.61)$ and no. of pods per plant $(0.45)$ suggesting early 

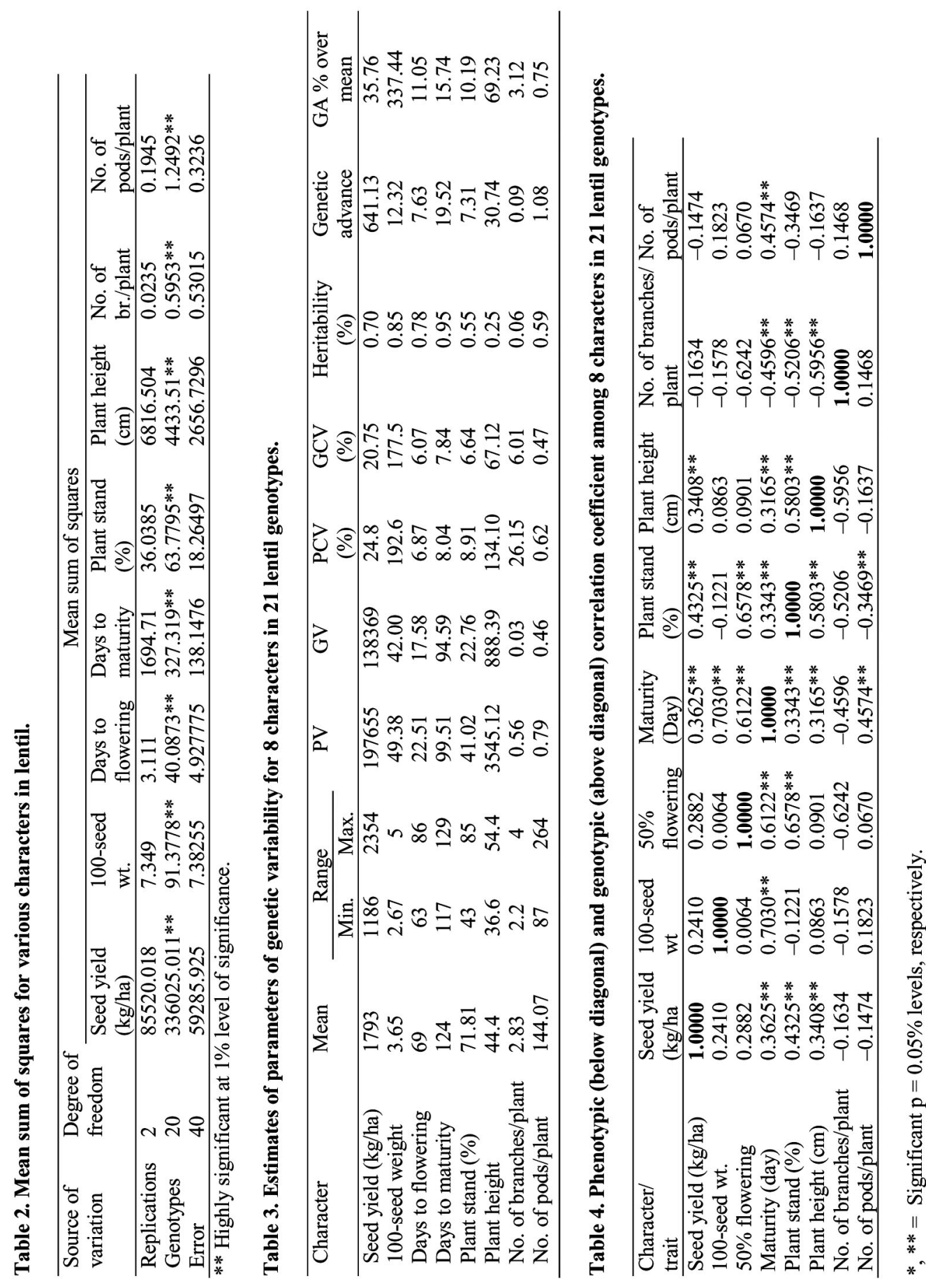
maturity or late maturity depend flowering which are directly correlated with seed yield and selection of more no. of pods plant gives maximum yield. Carrasco et al. (1985) also suggested that yield could be raised by selecting for earliness, tallness and more pods per plant-1, which is evident in the present study.

Table 5. Eigen values.

\begin{tabular}{lcclcccc}
\hline Number & $\begin{array}{c}\text { Eigen } \\
\text { value }\end{array}$ & $\begin{array}{c}\text { Per } \\
\text { cent }\end{array}$ & $\begin{array}{l}\text { Per } \\
\text { cent }\end{array}$ & $\begin{array}{c}\text { Cum } \\
\text { per cent }\end{array}$ & $\begin{array}{c}\text { Chi } \\
\text { square }\end{array}$ & df $\begin{array}{c}\text { Prob > } \\
\text { chi.sq }\end{array}$ \\
\hline 1 & 2.9957 & 37.446 & 37.446 & 59.086 & 27.453 & $0.0004^{*}$ \\
2 & 1.6996 & 21.245 & & 58.691 & 35.759 & 24.385 & 0.0642 \\
3 & 1.0575 & 13.219 & 71.910 & 23.045 & 19.481 & 0.2595 \\
4 & 0.9074 & 11.343 & & 83.253 & 16.447 & 14.288 & 0.3055 \\
5 & 0.6429 & 8.036 & & 91.289 & 8.714 & 9.628 & 0.5245 \\
6 & 0.2967 & 3.708 & $\square$ & 94.997 & 2.006 & 5.536 & 0.8908 \\
7 & 0.2582 & 3.227 & $\square$ & 98.224 & 1.187 & 2.350 & 0.6333 \\
8 & 0.1420 & 1.776 & $\square$ & 100.000 & 0.000 &. &. \\
\hline
\end{tabular}

Table 6. PC values of rotation component matrix for eight variables of 21 genotypes of lentil.

\begin{tabular}{lllll}
\hline Traits & \multicolumn{4}{c}{ Principal components } \\
\cline { 2 - 5 } & PC1 & PC2 & PC3 & PC4 \\
\hline Seed yield (kg/ha) & 0.604 & 0.023 & 0.275 & 0.656 \\
100-seed weight & 0.223 & 0.491 & 0.745 & 0.064 \\
50\% flowering & 0.609 & 0.284 & -0.548 & 0.266 \\
Maturity & 0.728 & -0.596 & -0.148 & -0.041 \\
Plant stand & 0.768 & -0.429 & -0.147 & 0.051 \\
Plant height & 0.712 & -0.299 & 0.263 & -0.351 \\
No. of branches/plant & -0.759 & 0.116 & -0.034 & 0.465 \\
Pods/plant & -0.085 & 0.857 & -0.112 & -0.239 \\
\hline
\end{tabular}

Rotation method: Varimax with Kaiser normalization.

Hundred-seed weight showed positive and significant correlation with maturity $(0.70)$ at genotypic level. Days to 50\% flowering revealed positive and significant correlation with maturity (0.61) and plant stand (0.65) and negative and significant correlation with number of branches/ plant (0.62). Plant height was exhibited positive and significant correlation with pant stand (0.58), seed yield (0.34) and maturity (0.31) and negative and significant correlation with number of branches/plant (0.59) at both phenotypic and genotypic level. Positive correlation of plant height with seed yield has also been reported by Kumar et al. (2004). Number pods per pant revealed significantly positive correlation with maturity and negative correlation with plant stand at genotypic level. Similar results were also reported by Tadesse et al. (2014).

In present experiment out of eight, only five components (PCs) exhibited more than Eigen value, and showed about $91.289 \%$ total variability among the studied traits (Table 5). So these five PCs were given due importance for further explanation. The PCs 1 showed $37.446 \%$ while, PC2, 
PC3, PC4 and PC5 exhibited 21.245, 13.219, 11.343 and 8.036 variability, respectively among the genotypes for the traits under study.

Table 7. Interpretation of rotated component matrix for the traits having values $> \pm 0.05$ in each PC.

\begin{tabular}{lllll}
\hline & PC1 & PC2 & PC3 & PC4 \\
\hline Characteristics & Plant stand & Pods/plant & 100-seed weight & Seed yield (kg/ha) \\
& Maturity & Maturity & Seed yield (kg/ha) & - \\
Plant height & 100 -seed weight & - & - \\
50\% flowering & - & - & - \\
& Seed yield (kg/ha) & - & - & - \\
\hline
\end{tabular}

Screen plot explained the percentage of variance associated with each principal component obtained by drawing a graph between eigen values and principal component numbers. PC1 showed 37.446 variability with Eigen value 2.9957 , which then declined gradually. Semi curve lines are observed in each PC. From the graph, it is clear that the maximum variation was observed in PC1 in comparison to other four PCs. So, selection of lines from this PC will be useful (Fig. 1).
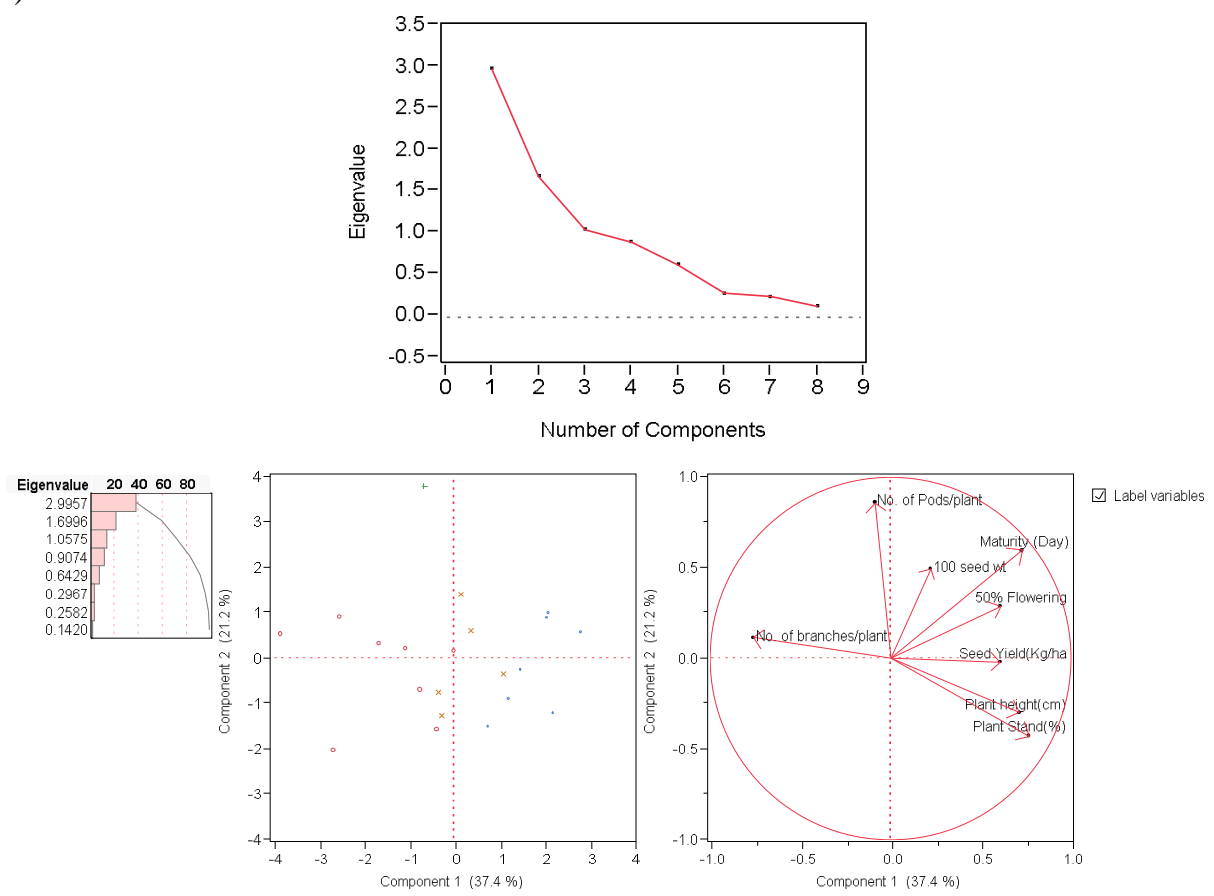

Fig. 1. Label of variables.

The rotated component matrix, sometimes referred to as the loadings, is the key output of principal components analysis. It contains estimates of the correlations between each of the variables and the estimated components. Rotated component matrix revealed that the PC1 which accounted for the highest variability $(37.446 \%)$ was mostly related to physiological and yield traits 
like plant stand, maturity, plant height, days to 50\% flowering and seed yield. PC2 was also dominating by yield related traits i.e. Maturity, 100 -seed weight and 50\% flowering. The PC3 was found to be dominating by yield traits i.e. 100-seed weight and seed yield. While, PC4 was found to be related to 100-seed weight and branches per plant (Tables 6 and 7).

Lentil production in India has always been important as it is the one of the most important Rabi crops in the country. In fact, India is the largest producer of the lentil crop in the world. On the basis of present investigation some important finding comes. High GCV was found for the characters, namely 100-seed weight, plant height and seed yield. Estimates of heritability in broad sense was high for most of the traits viz., days to maturity (0.95), 100-seed weight (0.85), days to flowering (0.78) and seed yield (0.70). High to moderate heritability coupled with high to moderate genetic advance as percentage of mean was exhibited for four traits viz., days to flowering, days to maturity, grain yield and 100-seed weight. Rotated component matrix revealed that the PC1 which accounted for the highest variability $(37.446 \%)$ was mostly related to physiological and yield traits like plant stand, maturity, plant height, days to $50 \%$ flowering and seed yield.

Variability gives a way to describe variance between characters and a scope for selection to plant. Yield in lentil could possibly be improved by increasing in traits viz., days to maturity, 100seed weight, days to flowering and seed yield. The presence of high heritability coupled with highexpected genetic advance indicated predominance of additive gene action in the expression of these characters and consequently greater chance of improving these traits through simple selection. Higher magnitude of genotypic correlation helps in selection for genetically controlled characters and gives a better chance for seed yield improvement.

\section{References}

Anonymous. 2018. Agriculture at a Glance. Available from http://www.agricoop.nic.in/Last accessed on 20 oct. 2018.

Al-Aysh FM 2014. Genetic variability, correlation and path coefficient analysis of yield and some yield components in landraces of lentil (Lens culinaris Medik.). Jordan J. Agricultural Sci. 10(4):737-750

Boye JI 2013. Lentil. http://www.thecanadianencyclopedia.com/en/.

Carrasco Diaz H, Leen, Gonzalez JP, Velazquez O, Garcia O and Lopez MT 1985. Phenotypic correlation in soybean and their importance in selection for yield. Ciencias de la Agricultura 24: 99-103.

Dewey DR and Lu HR 1959. A correlation and path coefficient analysis of components of crested wheat grass seed production. Agron. J. 51: 515-518.

Fisher RA and Yates F 1957. Statistical tables for biological, agricultural and medical research. Hafner, Pub. Co., Inc. New York. pp. 63.

Kumar R, Ravi K and Ojha CB 2004. Character association and cause effect analysis for spring season genotypes of mungbean (Vigna radiata L. Wilczek). Legume Res. 27: 32-36.

Massay WF 1965. Principal components regression in exploratory statistical research. J. Am. Stat. Assoc. 60: 234-246.

Mekonnen, F, Mekbib F, Kumar S, Ahmed S and Sharma R 2014. Agromorphological Traits Variability of the Ethiopian Lentil and Exotic Genotypes. Hindawi Publishing Corporation, Advances in Agriculture, Vol. 2014, Article ID 870864, 15 pages, http://dx.doi.org/10.1155/2014/870864.

Muehlbauer FJ, Cubero JI and Summerfield R J 1985. Lentil (Lens culinaris Medik.). p. 266-311. In: R.J. Summerfield and E.H. Roberts (eds.), Grain Legume Crops. Collins, 8 Grafton Street, London, UK.

Ramanujam, S. and Rai B 1963. Analysis of yield components in Brasssica comprestris var. yellow sarson. Indian J. Genet. and Plant Breeding 23: 312-319.

Robinson HF, Comstock RE and Harvey PH 1949. Estimates of heritability and degree of dominance in corn. Agron. J. 41: 353-359. 
Robinson HF, Comstock RE and Harvey PH 1951. Genotypic and phenotypic correlations in corn and their implications in selection. Agron. J. 43: 262-267.

Tadesse T, Leggesse T, Mulugeta B and Sefera G 2014. Correlation and path coefficient analysis of yield and yield components in lentil (Lens culinaris Medik.) germplasm in the highlands of Bale, Ethiopia. International J. Biodiversity and Conservation 6(1): 115-120

Tyagi SD and Khan MH 2010. Studies on genetic variability and interrelationship among the different traits in Microsperma lentil (Lens culinaris Medik.). Journal of Agricultural Biotechnology and Sustainable Development 2(1): 015-020.

Williams PC, Bhatty RS, Deshpande SS, Hussein LA and Savage GP 1994. Improving nutritional quality of cool season food legumes. p. 113-129. In: FJ Muehlbauer and WJ Kaiser (Eds.), Expanding the Production and Use of Cool Season Food Legumes. Kluwer Academic Publishers, Dordrecht. The Netherlands.

(Manuscript received on 31 October, 2018; revised on 5 august, 2019) 